\title{
主筋が単配筋された薄肉断面鉄筋コンクリート梁部材の せん断終局耐力評価 \\ EVALUATION OF ULTIMATE SHEAR STRENGTH OF REINFORCED CONCRETE THIN BEAMS WITH SINGLY ARRANGED REINFORCING BARS
}

\author{
磯 雅 人*, 郷 雅 紀** \\ Masato ISO and Masanori GOH
}

\begin{abstract}
The objectives of this research are to clarify the shear behavior of reinforced concrete thin beams with main reinforcement arranged singly and stirrup of no closed-type and to derive the formula to evaluate the ultimate shear strengths. A total of 10 specimens were constructed and tested under simulated seismic loading. The primary test variables were amount of shear reinforcement, compressive strength of the concrete and the shape of stirrup. As the test results, the structural performance is degraded in comparison with $\mathrm{R} / \mathrm{C}$ beams with main reinforcement arranged doubly and stirrup of closed-type. The reason is as follows.

1. Damage of concrete is concentrated on the core area of cross section.

2. The shear reinforcement effect of stirrup, which is no closed-type, decrease in comparison with stirrup of closed-type. Because of being determined by anchorage ability of $180^{\circ}$ hook.

Then being based on above results, the formula to evaluate the ultimate shear strengths of $\mathrm{R} / \mathrm{C}$ thin beams with main reinforcement arranged singly is developed. Fairly good agreement between experimental and calculated results of the ultimate shear strength is shown.
\end{abstract}

Keywords : R/C thin Beam, Single reinforcing bar, Ultimate shear strength, Shear reinforcing bar, $180^{\circ}$ hook, Anchorage 薄肉断面 RC 梁，単配筋，せん断終局耐力，せん断補強筋， $180^{\circ}$ フック，定着

\section{1. はじめに}

木造あるいは軽量鉄骨の住宅における布基礎の立上がり部は，鉄 筋コンクリート造の薄肉断面部材となる。そのため, かぶり厚さな どを考えると，主筋は幅方向に1列しか配筋することができずに単 配筋となる。また，せん断補強筋の定着部は，通常， $180^{\circ}$ フック となり，非閉鎖型形状の補強筋となる。そのため，主筋が複配筋， せん断補強筋が閉鎖型となる従来の梁配筋とは異なる。また, 壁式 構造関係設計規準集・同解説（壁式鉄筋コンクリート造編） 1 )の 8 条: 壁梁構造の規定では，「単配筋の場合には，鉄筋端部に $180^{\circ}$ フ ックを付けて定着する。」との記述があり, 主筋が単配筋, せん断補 強筋が非閉鎖型となることを許容している。つまり，壁式構造の壁 梁も住宅の布基礎の配筋と同様となるケースがある。

ところで，せん断補強筋が非閉鎖型の場合，コアコンクリートに 対する拘束力は閉鎖型補強筋に比べて弱く, 構造性能の低下が危惧 される。

園部, 米澤ら 2)はせん断補強量をほぼ同一にして, 主筋を複配筋, せん断補強筋を閉鎖型とした薄肉断面の $\mathrm{RC}$ 梁部材と主筋を単配筋, せん断補強筋を非閉鎖型とした薄肉断面の $\mathrm{RC}$ 梁部材の曲げせん断 実験を実施している。補強筋の形状を非閉鎖型とした試験体の勒性
能は，閉鎖型とした試験体に比べて低下寸ることを報告している。 永坂ら 3) は主筋を複配筋とし，せん断補強量を同一にして，せん 断補強笳の形状を非閉鎖型，閉鎖型とした RC 梁部材のせん断実験 を実施している。実験の結果，せん断補強筋を非閉鎖型とした RC 梁のせん断耐力は，閉鎖型とした $\mathrm{RC}$ 梁に比較して，せん断耐力が 低下寸ることを報告している。さらに，閉鎖型補強筋の RC 梁部材 を対象とした既往のせん断終局強度評価式では，実験結果を適切に 評価できないことを指摘している。

また，松崎，金子ら ${ }^{4)}$ は，主筋が単配筋，補強筋が非閉鎖型の RC 梁部材のせん断実験を実施している。破壊は，梁上面に割裂ひび割 れが進展し，最終破壊は上面割裂ひび割れを起因とし，極めて脆性 的な破壊を示すことを報告している。

しかし，主筋が単配筋された RC 梁部材の研究事例は極めて少な く, その構造性能は不明な点が多く残されているのが現状である。 また，壁式構造の壁梁の終局せん断耐力は，主筋が複配筋，補強筋 が閉鎖型とした RC 梁のせん断実験から導出された大野・荒川式が 準用されている1)。本来の意味からすれば主筋が単配筋，非閉鎖型 補強筋の RC 梁については, 適用の範囲外と考えられる。以上のこ とから現段階では，主筋を単配筋，補強筋を非閉鎖型とした RC 梁
福井大学大学院工学研究科建築建設工学専攻 講師・博士 (工学)

** 名古屋大学環境学研究科都市環境学専攻 大学院生・修士 (工学)
Assistant Prof., Architecture and Civil Eng., Graduate School of Eng., Univ, of Fukui, Dr. Eng.

Graduate Student, Department of Environmental Engineering and Architecture, Graduate School of Environmental Studies, Nagoya University, M. Eng. 
表 1 試験体一覧

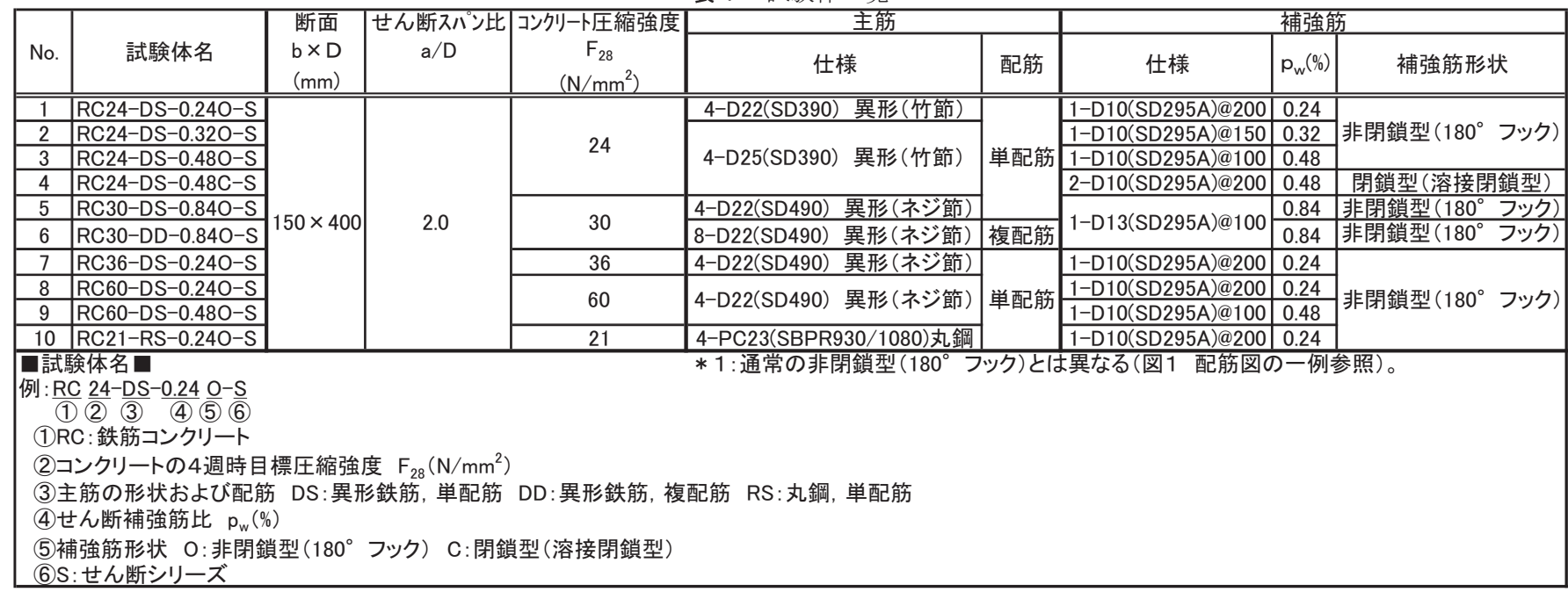

表2 鉄筋の力学的性質

\begin{tabular}{|c|c|c|c|c|c|c|}
\hline $\begin{array}{c}\text { 試験体 } \\
\text { No. }\end{array}$ & 使用部位 ： 鉄筋の種類 & \begin{tabular}{|l|} 
降伏点 \\
$\left(\mathrm{N} / \mathrm{mm}^{2}\right)$ \\
\end{tabular} & $\begin{array}{l}\text { 引張強度 } \\
\left(\mathrm{N} / \mathrm{mm}^{2}\right)\end{array}$ & $\begin{array}{c}\text { 降伏ひずみ度 } \\
(\mu)\end{array}$ & $\begin{array}{c}\text { ヤング係数 } \\
\times 10^{5}\left(\mathrm{~N} / \mathrm{mm}^{2}\right)\end{array}$ & \begin{tabular}{|c|} 
伸び率 \\
$(\%)$
\end{tabular} \\
\hline No.1 & $\begin{array}{l}\text { 主 筋：D22 (SD390) } \\
\end{array}$ & 436 & 595 & 2480 & 1.76 & 20.7 \\
\hline No.2, 3, 4 & 主 筋：D25（SD390） & 437 & 595 & 2440 & 1.79 & 19.2 \\
\hline No.5, 6 & 主 筋: D22（SD490） & 509 & 678 & 2730 & 1.94 & 16.1 \\
\hline No.7 & 主 筋：D22（SD490） & 537 & 699 & 2860 & 1.97 & 17.4 \\
\hline No.8, 9 & 主 筋：D22（SD490） & 537 & 699 & 2860 & 1.97 & 17.4 \\
\hline No. 10 & $\begin{array}{ll} & \text { 主 筋: } \\
\text { PC23 } & \text { (SBPRR930/1080) }\end{array}$ & 1000 & 1120 & 7210 & 1.91 & 14.3 \\
\hline No.1, 2, 3, 4 & 補強筋：D10 (SD295A) & 351 & 473 & 1950 & 1.80 & 31.5 \\
\hline No.5, 6 & 補強筋：D13（SD295A） & 346 & 495 & 1820 & 1.92 & 27.2 \\
\hline No.7 & \begin{tabular}{|l} 
補強筋：D10 (SD295A) \\
\end{tabular} & 346 & 483 & 1880 & 1.88 & 29.3 \\
\hline No.8, 9 & 補強筋：D10（SD295A） & 348 & 481 & 1880 & 1.88 & 29.3 \\
\hline No.10 & 補強筋：D10（SD295A） & 354 & 500 & 1960 & 1.76 & 29.7 \\
\hline
\end{tabular}

表3 コンクリートの力学的性質

\begin{tabular}{|l||c|c|c|c|c|}
\hline $\begin{array}{l}\text { 試験体 } \\
\text { No. }\end{array}$ & 材齢(養生) & $\begin{array}{c}\text { 圧縮強度割裂引張強度 } \\
\left(\mathrm{N} / \mathrm{mm}^{2}\right)\end{array}$ & $\begin{array}{c}\text { ポアソン比 } \\
\left(\mathrm{N} / \mathrm{mm}^{2}\right)\end{array}$ & $\begin{array}{c}\text { ヤング係数 } \\
\times 10^{4}\left(\mathrm{~N} / \mathrm{mm}^{2}\right)\end{array}$ \\
\hline \hline No.1, 2, 3 & 54 (封緘) & 31.6 & 2.37 & 0.180 & 2.37 \\
\hline No.4 & 64(封緘) & 32.5 & 2.55 & 0.181 & 2.45 \\
\hline No.5 & 35 (封緘) & 33.1 & 2.41 & 0.156 & 2.49 \\
\hline No.6 & 39 (封緘) & 34.5 & 2.49 & 0.154 & 2.49 \\
\hline No.7 & 40 (封緘) & 40.3 & 2.56 & 0.176 & 2.25 \\
\hline No.8, 9 & 31 35(封緘) & 55.4 & 3.71 & 0.182 & 2.74 \\
\hline No.10 & 42(封緘) & 21.1 & 1.78 & 0.187 & 2.00 \\
\hline
\end{tabular}

C.L.

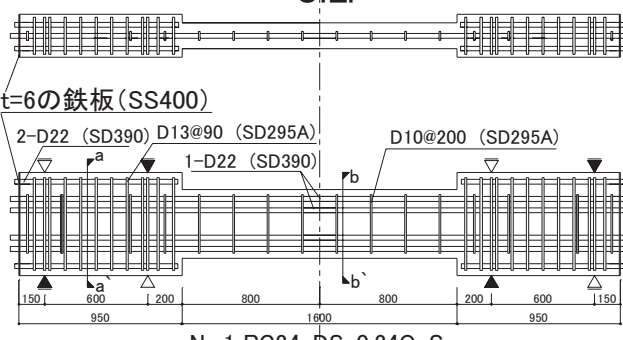
No.1 RC24-DS-0.240-S

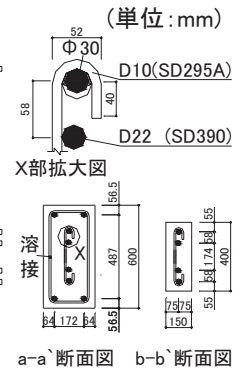

表 1 に試験体一覧, 表 2, 表 3 に鉄筋およびコンクリートの力学的 性質, 図1に配筋図の一例を示す。共通要因は, 断面 $b \times D=150 \times$ $400(\mathrm{~mm})$, せん断スパン比 $\mathrm{a} / \mathrm{D}=2.0$ である。変動要因は, コンクリ 一下圧縮強度, 主筋の形状, 主筋の配筋, せん断補強筋比 $\mathrm{p}_{\mathrm{w}}$, 補強 筋形状の 5 要因である。コンクリートの 4 週時目標圧縮強度 $\mathrm{F}_{28}$ は $21,24,30,36,60\left(\mathrm{~N} / \mathrm{mm}^{2}\right)$ の 5 水準, 主筋の形状は異形, 丸鋼の 2 水準, 主筋の配筋は単配筋, 複配筋の 2 水準, せん断補強筋比 $\mathrm{p}_{\mathrm{w}}$ は $0.24,0.32,0.48,0.84(\%) の 4$ 水準, 補強筋形状は補強筋の定 着部が $180^{\circ}$ フックの非閉鎖型補強筋（以下，非閉鎖型）, 溶接閉鎖 型補強筋（以下, 閉鎖型）の 2 水準であり, 補強筋端部の詳細は図 1中の X 部拡大図に示した。以上, 試験体総数は 10 体である。なお, 破壊モードは，せん断破壊が先行するように設計を行った。

No.1, No.2, No.3 試験体およびNo.8, No.9 試験体は, コンクリ 一ト強度をほぼ共通にして, せん断補強筋比のみを変動させている。 以上の試験体により, せん断性状に与えるせん断補強筋比の影響を 明らかにする。また，No.1，No.7，No.8 試験体およびNo.3，No.9 試験体は, せん断補強筋比を共通にして, コンクリート強度のみを 変動させている。以上の試験体により, コンクリート強度の影響を
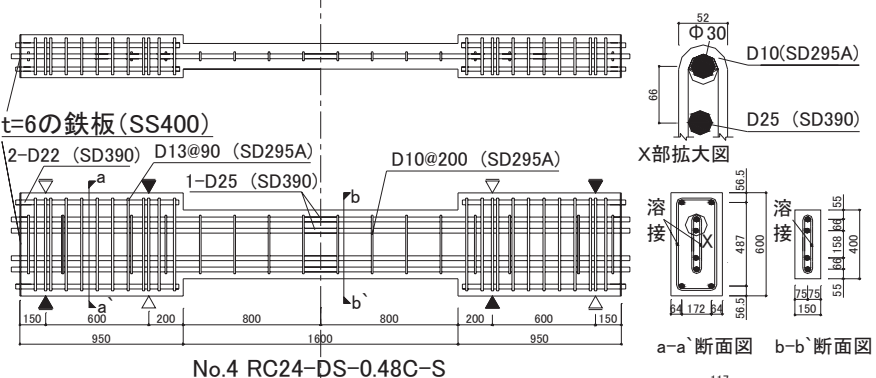

$\mathrm{a}$-a'断面図 $\mathrm{b}$-b’断面図
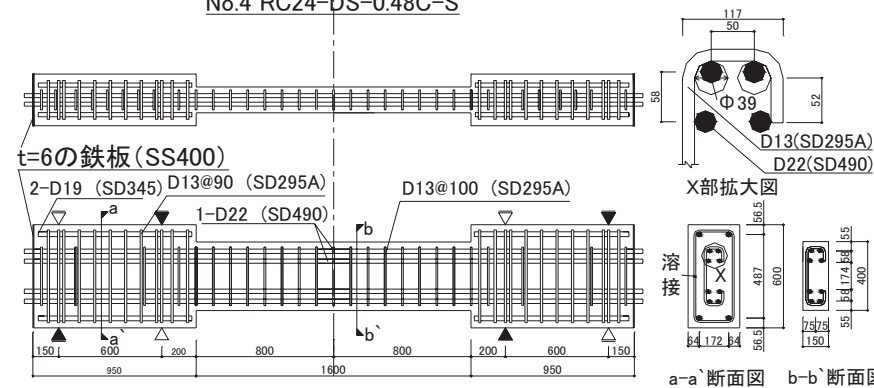

X部拡大図 D22(SD490)

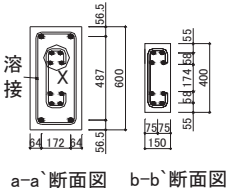

No.6 RC30-DD-0.840-S

図 1 配筋図の一例 
表4 実験結果一覧

\begin{tabular}{|c|c|c|c|c|c|c|c|c|c|c|c|c|}
\hline \multirow[b]{2}{*}{ No. } & \multirow[b]{2}{*}{ 試験体名 } & \multicolumn{2}{|c|}{ 曲げひび割れ } & \multicolumn{2}{|c|}{ せん断ひび割れ } & \multicolumn{2}{|c|}{ 上面割裂 } & \multicolumn{2}{|c|}{ 下面割裂 } & \multicolumn{2}{|c|}{ 最大耐力 } & \multirow[t]{2}{*}{ 破壊モ一ド } \\
\hline & & $\begin{array}{l}{ }_{e} Q_{m c} \\
(k N) \\
\end{array}$ & $\begin{array}{l}\mathrm{e}^{\delta} \delta_{\mathrm{mc}} \\
(\mathrm{mm}) \\
\end{array}$ & $\begin{array}{l}e^{Q_{s c}} \\
(k N)\end{array}$ & $\begin{array}{l}\mathrm{e}^{\delta} \delta_{\mathrm{sc}} \\
(\mathrm{mm})\end{array}$ & $\begin{array}{l}e^{Q_{t s c}} \\
(k N)\end{array}$ & $\begin{array}{l}\mathrm{e}^{\delta}{ }_{\mathrm{tsc}} \\
(\mathrm{mm})\end{array}$ & $\begin{array}{l}e^{Q_{b s c}} \\
(k N)\end{array}$ & $\begin{array}{l}\mathrm{e}^{\delta_{\mathrm{bsc}}} \\
(\mathrm{mm})\end{array}$ & $\begin{array}{l}{ }_{e} Q_{\text {su }} \\
(\mathrm{kN}) \\
\end{array}$ & $\begin{array}{l}\mathrm{e}^{\delta_{\mathrm{su}}} \\
(\mathrm{mm})\end{array}$ & \\
\hline \multirow[t]{2}{*}{1} & \multirow[t]{2}{*}{ RC24-DS-0.24O-S } & 14.8 & 0.668 & 51.6 & 3.27 & 82.9 & 8.07 & - & - & 95.8 & 12.2 & \multirow{2}{*}{$\begin{array}{c}\text { せん断引張破壊 } \\
\text { (上·下面割裂ひひ割れ) }\end{array}$} \\
\hline & & -15.0 & 0.038 & -44.2 & -2.35 & -29.7 & -1.01 & - & - & -98.1 & -12.3 & \\
\hline \multirow[t]{2}{*}{2} & \multirow[t]{2}{*}{ RC24-DS-0.32O-S } & 18.2 & 0.555 & 51.4 & 3.32 & 47.8 & 2.89 & - & - & 98.7 & 12.2 & \multirow{2}{*}{$\begin{array}{c}\text { せん断引張破壊 } \\
\text { (上·下面割裂ひび割れ) }\end{array}$} \\
\hline & & -14.5 & 0.093 & -44.1 & -1.91 & -58.4 & -3.29 & - & - & -98.9 & -12.1 & \\
\hline \multirow[t]{2}{*}{3} & \multirow[t]{2}{*}{ RC24-DS-0.48O-S } & 14.8 & 0.405 & 36.9 & 1.90 & 87.2 & 8.06 & - & - & 109.0 & 12.0 & \multirow{2}{*}{$\begin{array}{c}\text { せん断引張破壊 } \\
\text { (上·下面割裂ひび割れ) } \\
\end{array}$} \\
\hline & & -11.1 & 0.190 & -44.3 & -2.50 & -58.2 & -4.09 & - & - & -102.9 & -12.2 & \\
\hline \multirow[t]{2}{*}{4} & \multirow{2}{*}{ RC24-DS-0.48C-S } & 8.4 & 0.255 & 47.3 & 3.00 & 61.3 & 4.66 & - & - & 126.1 & 15.4 & \multirow{2}{*}{$\begin{array}{c}\text { せん断引張破壊 } \\
\text { (上·下面割裂ひび割れ) }\end{array}$} \\
\hline & & -17.5 & -0.020 & -47.8 & -2.30 & -52.1 & -2.65 & - & - & -117.3 & -12.1 & \\
\hline \multirow[t]{2}{*}{5} & \multirow[t]{2}{*}{ RC30-DS-0.840-S } & 30.1 & 0.605 & 55.3 & 2.27 & 51.2 & 1.95 & 51.2 & 1.95 & 149.4 & 16.0 & \multirow{2}{*}{$\begin{array}{c}\text { せん断引張破壊 } \\
\text { (上·下面割裂ひび割れ) }\end{array}$} \\
\hline & & -21.2 & -0.150 & -58.7 & -2.69 & -64.4 & -3.28 & -52.1 & -2.11 & -145.8 & -16.2 & \\
\hline \multirow[t]{2}{*}{6} & \multirow[t]{2}{*}{ RC30-DD-0.840-S } & 36.2 & 0.693 & 70.4 & 2.03 & 124.5 & 24.05 & 125.5 & 16.11 & 161.6 & 12.0 & \multirow{2}{*}{ 二段筋付着割裂破壊 } \\
\hline & & -29.2 & -0.383 & -80.5 & -3.58 & -107.1 & -16.09 & -99.4 & -24.30 & -139.2 & -12.0 & \\
\hline \multirow[t]{2}{*}{7} & \multirow[t]{2}{*}{ RC36-DS-0.240-S } & 9.3 & 0.238 & 48.8 & 3.69 & 28.9 & 1.64 & 34.7 & 2.06 & 99.1 & 12.1 & \multirow{2}{*}{$\begin{array}{c}\text { せん断引張破壊 } \\
\text { (上·下面割裂ひび割れ) }\end{array}$} \\
\hline & & -7.4 & 0.700 & -64.9 & -5.68 & -40.3 & -2.56 & -40.3 & -2.56 & -87.9 & -12.3 & \\
\hline \multirow[t]{2}{*}{8} & \multirow{2}{*}{ RC60-DS-0.240-S } & 9.42 & 0.268 & 54.0 & 3.71 & 86.4 & 8.00 & 54.0 & 3.71 & 107.1 & 11.6 & \multirow{2}{*}{$\begin{array}{c}\text { せん断引張破壊 } \\
\text { (上·下面割裂ひび割れ) }\end{array}$} \\
\hline & & -7.35 & 0.470 & -44.6 & -3.60 & -44.6 & -3.60 & -75.8 & -8.01 & -87.4 & -12.0 & \\
\hline 9 & RC60-DS-0.480-S & 12.86 & 0.283 & 50.5 & 2.93 & 39.5 & 1.96 & 50.5 & 2.93 & 143.7 & 16.0 & せん断引張破壊 \\
\hline & & -1.45 & 0.695 & -49.8 & -4.14 & -97.2 & -12.04 & -49.8 & -4.14 & -128.2 & -16.1 & （上·下面割裂ひび割れ） \\
\hline 10 & RC21-RS-0.240-S & 7.6 & 0.133 & 2 & 2 & 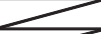 & $\sim$ & 2 & 2 & 68.6 & 24.1 & \\
\hline & & -5.8 & 1.488 & -28.0 & -6.82 & & & -43.6 & -12.01 & -67.8 & -24.1 & \\
\hline
\end{tabular}

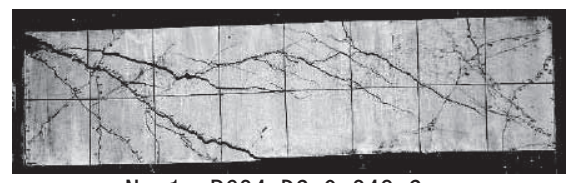

No. 1 RC24-DS-0. 240-S

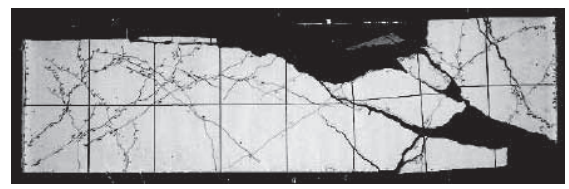

NNo. 4 RC24-DS-0. 48C-S

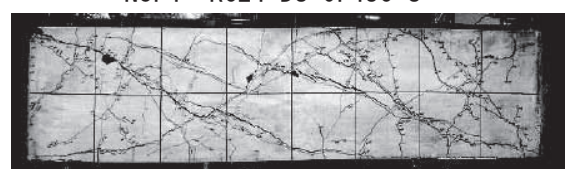

No. 7 RC36-DS-0.240-S

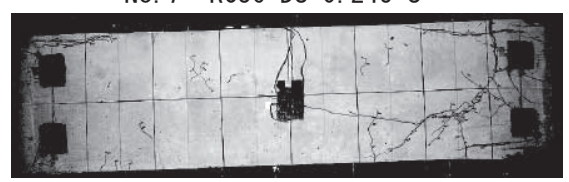

No. 10 RC21-RS-0.240-S

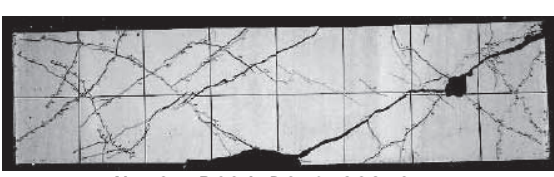

No. 2 RC24-DS-0.320-S

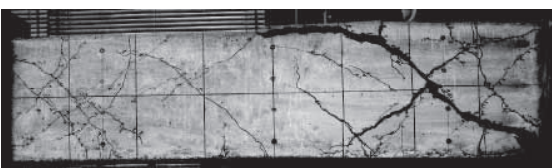

No. 5 RC30-DS-0.840-S

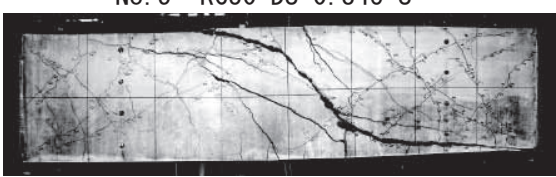

正面

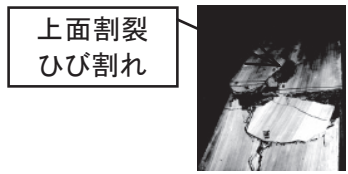

No. 8 RC60-DS-0.240-S

写真 1 最終破壊状況

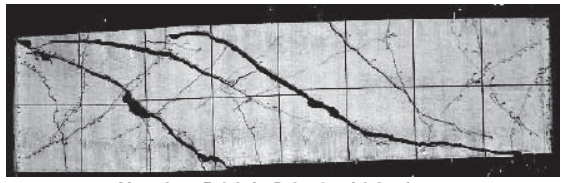

No. 3 RC24-DS-0. 480-S

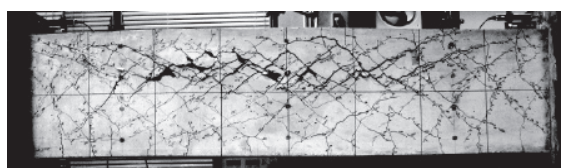

No. 6 RC30-DD-0.840-S
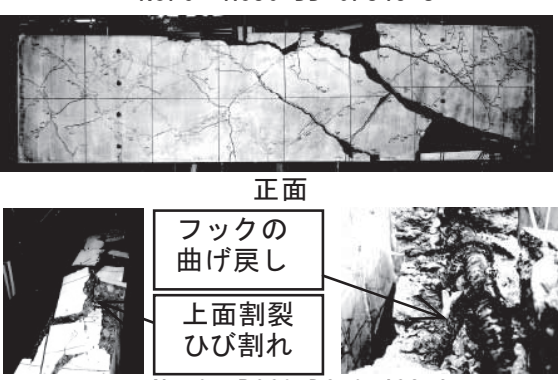

正面

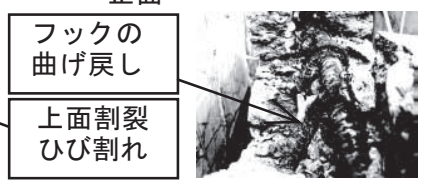

No. 9 RC60-DS-0. 480-S

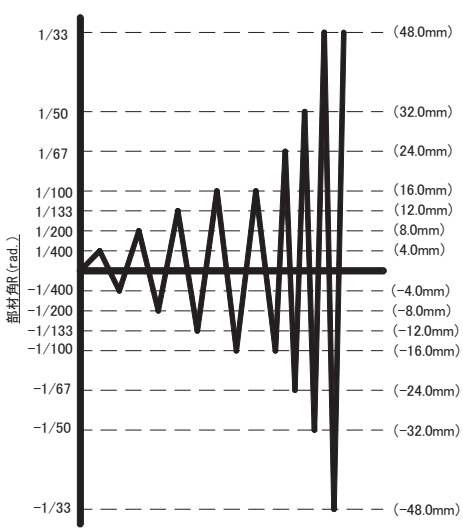

図2 加力サイクル
明らかにする。No.4 試験体は，せん断性状に与える補強筋形状の影 響を明らかにするために計画した試験体である。補強筋形状が非閉 鎖型であるNo.3 試験体と閉鎖型としたNo.4 試験体との比較により その影響を確認する。No.6 試験体は, せん断性状に与える主筋の配 筋の影響を明らかにするために計画した試験体である。主筋が単配 筋の No.5 試験体と複配筋の No.6 試験体との比較によりその影響を 確認する。No.10 試験体は，アーチ機構によるせん断終局耐力を評 価する試験体である。トラス機構が成立しないように主筋を丸鋼と し，グリースを塗布して主筋の付着を除去した。

図2に加力サイクルを示す。加力は逆対称モーメントが生じるように 大野式加力とした。加力サイクルは, 部材角 $\mathrm{R}=1 / 400,1 / 200,1 / 133(\mathrm{rad}$. をそれぞれ 1 サイクル， $\mathrm{R}=1 / 100(\mathrm{rad}$.$) を 2$ サイクル， $\mathrm{R}=1 / 67 ， 1 / 50$, 1/33(rad.)をそれぞれ 1 サイクル行うことを原則とし，正負交番繰返し載 荷とした。ひずみ計測は主筋およびせん断補強筋について行い，変 位測定は相対変位, 曲げ変形, せん断変形, 材端の回転変形につい
て行った。

\section{3. 実験結果}

表4に実験結果一覧を 示す。表中の $\mathrm{Q}$ および $\delta$ は, 各ひび割れ発生時に試 験区間部分に生じている せん断力および相対変位 を示している。

\section{1 破壊性状}

写真 1 に最終破壊状況

を示寸。No.6, No.10 試験体以外の試験体の破壊経過は，最初に材 端部に曲げひび割れ，次いで，せん断ひび割れ，上・下面に割裂ひ び割れが生じた。その後は, 荷重の増加とともにひび割れが分散, 進展する。最終破壊は脆性的であり，上・下面に割裂ひび割れをと 
もなうせん断引張破壊の性状を示した。同試験体に関して実験終了 後にコンクリート部分をはつり観察したところ, 補強筋端部の $180^{\circ}$ フック部分が曲げ戻されていることが確認された。また, 補 強筋外周部のカバーコンクリートの損傷は,

ひび割れが生じているものの健全なコンク リートが多く残されていた。それに対して， 補強筋に囲まれたコアコンクリートの損傷 は，カバーコンクリートに比べて損傷が大 きくなる傾向が認められた。

No.6 試験体の破壊経過は, 最初に材端部 に曲げひび割れ, 次いで, せん断ひび割れ,

上・下面に割裂ひび割れが生じた。最終破 壊状況は, 二段筋部分の付着割裂破壊を示 した。

No.10 試験体の破壊経過は, 最初に材端 部に曲げひび割れ，次いで，せん断ひび割 れ，下面に割裂ひび割れが生じた。最終破 壊は，材端圧縮部コンクリートの圧縮破壊 の性状を示した。また, 全体のひび割れ本 数は他の試験体に比較して極めて少なく, ひび割れは材端部に集中する傾向が認めら れた。

\section{2 変形性状}

図3に各試験体のせん断力 $(\mathrm{Q})$ - 相対変 位（ס）関係を示す。初期剛性は, コンクリ 一ト圧縮強度の違いによる顕著な差異は認 められず，ほぼ同程度であった。これは， 乾燥収縮による微細なひび割れによる影響 等により明確な差異が認められなかったと 推察される。

せん断ひび割れ発生後から最大荷重まで の剛性は，せん断補強筋比の増加とともに 高くなる傾向が認められたが，コンクリー 卜圧縮強度の違いによる顕著な差異は認め られない。

最大耐力時の変形は，二段筋の付着割裂 破壊を示した No.6 試験体および No.4,

No.5, No.9 試験体を除くせん断引張破壊 を示した試験体は，部材角 $\mathrm{R}=1 / 133(\mathrm{rad}$ ) で最大耐力にいたっている。しかし, 補強 筋形状を閉鎖型とした No.4 試験体, $\mathrm{p}_{\mathrm{w}}=0.84(\%)$ とした No.5 試験体, コンクリ 一ト目標圧縮強度 $\mathrm{F}_{28}$ を $60\left(\mathrm{~N} / \mathrm{mm}^{2}\right)$ とした No.9 試験体の最大耐力時の変形は, 部材角 $\mathrm{R}=1 / 100$ (rad.)程度となっており, やや大き くなる傾向が認められた。一方, アーチ機 構のせん断終局耐力を確認するための No.10 試験体の最大耐力時の変形は, $\mathrm{R}=1 / 67$ (rad.)程度であり, 他の試験体に比 べて大きな変形となっている。これは，主
筋の付着を除去したために主筋の抜け出し変位が大きくなり，その ために最大耐力時の変形が大きくなったと推察される。

最大耐力後の変形性状に関しては, せん断引張破壊を示した No.1
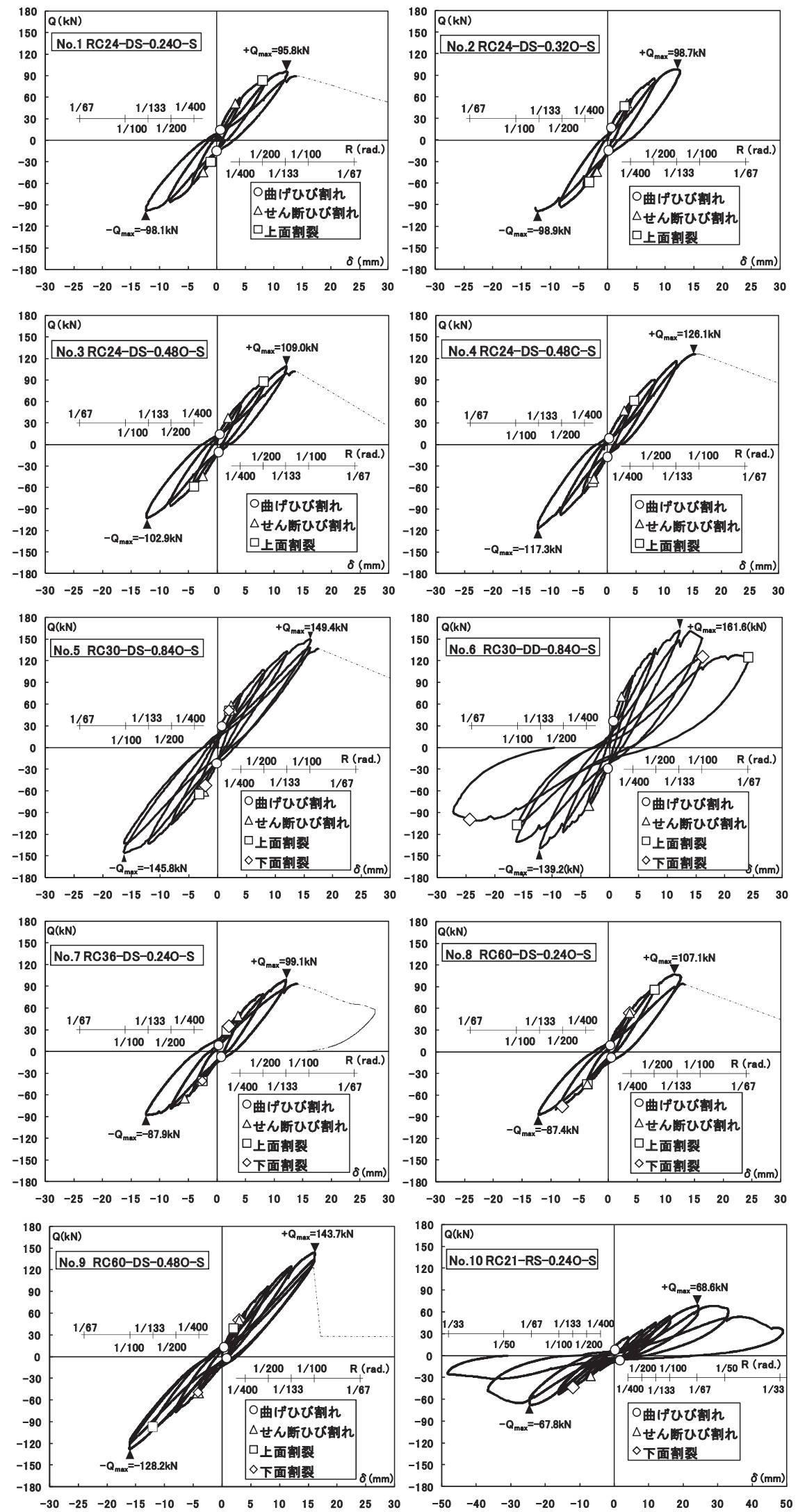

図3 世九断力 $(Q)$ - 相対変位 $(\delta)$ 関係 


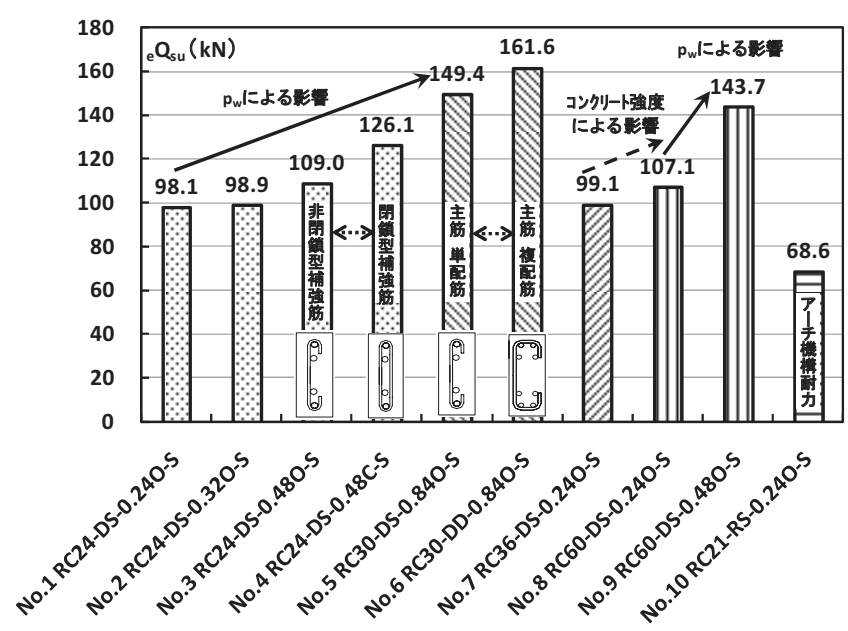

図4 最大耐力実験值 $\left({ }_{\mathrm{e}} Q_{\mathrm{su}}\right)$ の比較

～5，No.7～9 試験体は，急激に耐力を低下させる脆性的な性状を 示した。一方，二段筋の付着割裂破壊を示した No.6 試験体および 圧縮ストラットの圧縮破壊を示したNo.10試験体は急激な耐力低下 は見られず，徐々に耐力を低下させる性状を示した。

\section{3 せん断終局耐力}

図4に最大耐力実験值 $\left({ }_{\mathrm{e}} \mathrm{Q}_{\mathrm{su}}\right)$ の比較を示す。せん断補強筋比 $\mathrm{p}_{\mathrm{w}}$ の影響では, コンクリート圧縮強度 $\sigma_{\mathrm{B}}$ が 31.6〜 33.1( $\left.\mathrm{N} / \mathrm{mm}^{2}\right)$ とほぼ 同等である No.1, No.2, No.3, No.5 試験体で比較した場合, $\mathrm{p}_{\mathrm{w}}$ の 上昇とともに最大耐力は上昇する傾向が認められた。また， $\sigma_{\mathrm{B}}=55.4\left(\mathrm{~N} / \mathrm{mm}^{2}\right)$ の No.8, No.9 試験体で比較した場合でも, 同様に $\mathrm{p}_{\mathrm{w}}$ の上昇とともに最大耐力は上昇する傾向が認められた。

コンクリート圧縮強度 $\sigma_{\mathrm{B}}$ の影響では, $\mathrm{p}_{\mathrm{w}}=0.24(\%)$ である $\sigma_{\mathrm{B}}=31.6\left(\mathrm{~N} / \mathrm{mm}^{2}\right)$ の No.1 試験体, $\sigma_{\mathrm{B}}=40.3\left(\mathrm{~N} / \mathrm{mm}^{2}\right)$ の No.7 試験体, $\sigma_{\mathrm{B}}=55.4\left(\mathrm{~N} / \mathrm{mm}^{2}\right)$ の No.8 試験体で比較した場合， $\sigma_{\mathrm{B}}$ の上昇とともに 最大耐力は上昇する傾向が認められた。また, $\mathrm{p}_{\mathrm{w}}=0.48(\%)$ である $\sigma_{\mathrm{B}}=31.6\left(\mathrm{~N} / \mathrm{mm}^{2}\right)$ の No.3 試験体, $\sigma_{\mathrm{B}}=55.4\left(\mathrm{~N} / \mathrm{mm}^{2}\right)$ の No.9 試験体で 比較した場合でも, 同様に $\sigma_{\mathrm{B}}$ の上昇とともに最大耐力は上昇する傾 向が認められた。

補強筋形状による影響では，閉鎖型とした No.4 試験体の最大耐力は 非閉鎖型とした No.3 試験体に比較して大きく, 閉鎖型にすることによ り最大耐力は上昇する傾向が認められた。No.4 試験体の耐力が上昇し た要因であるが， $180^{\circ}$ フックの非閉鎖型補強筋は, 試験後の観察でフ ックが曲げ戻されていた。一方, 閉鎖型補強筋の試験体では, そのよう な性状は確認されていない。以上のことから, 閉鎖型補強筋における補 強筋端部の定着能力および主筋の拘束力は, 非閉鎖型補強筋に比較して 高く, そのために耐力が向上したと推察される。

主筋の配筋による影響では, 複配筋とした No.6 試験体の最大耐力は, 主筋を単配筋とした No.5 試験体に比較して大きく, 主筋を複配筋に寸 ることにより最大耐力は上昇する傾向が認められた。これは, 主筋のダ ボ効果により耐力が上昇したことが考えられる。また，トラス機構によ るせん断抵抗機構を考えれば, 主筋が並列して 2 列に並ぶためにトラス 機構の圧縮束応力の作用幅が広がるとともに, 主筋の周長が 2 倍に増え たことにより主筋の付着力が増加して, トラス機構の耐力を向上させた ことが考えられる。

アーチ機構の耐力を確認するために主筋の付着力を除去した No.10
表5 計算結果一覧

\begin{tabular}{|c|c|c|c|c|c|c|c|c|}
\hline \multirow{2}{*}{ No. } & \multirow{2}{*}{ 試験体名 } & \multirow{2}{*}{\begin{tabular}{|c|} 
最大耐力 \\
(実験値) \\
$\mathrm{Q}_{\mathrm{su}}(\mathrm{kN})$ \\
\end{tabular}} & \multicolumn{3}{|c|}{ せん断終局強度計算値 } & \multicolumn{3}{|c|}{ 比較値=実験值/計算値 } \\
\hline & & & ${ }_{\mathrm{b}} \mathrm{Q}_{\mathrm{su}}(\mathrm{kN})$ & $\mathrm{V}_{\mathrm{u}}(\mathrm{kN})$ & $\mathrm{MA}_{\mathrm{MA}} \mathrm{V}_{\mathrm{u}}(\mathrm{kN})$ & ${ }_{\mathrm{e}} \mathrm{Q}_{\mathrm{su}} /{ }_{\mathrm{b}} \mathrm{Q}_{\mathrm{su}}$ & ${ }_{e} Q_{s u} / V_{u}$ & ${ }_{e} Q_{s u} / M_{A} V_{u}$ \\
\hline & RC24-DS-0.24O-S & 98.1 & 78.2 & 120.4 & 79.5 & 1.25 & 0.81 & 1.23 \\
\hline & RC24-DS-0.32O-S & 98.9 & 84.6 & 139.5 & 88.9 & 1.17 & 0.71 & 1.11 \\
\hline & RC24-DS- $0.480-S$ & 109.0 & 92.9 & 177.6 & 101.8 & 1.17 & 0.61 & 1.07 \\
\hline & RC24-DS-0.48C-S & 126.1 & 93.7 & 178.9 & 123.8 & 1.35 & 0.70 & 1.02 \\
\hline & RC30-DS-0.840-S & 149.4 & 107.7 & 265.6 & 109.7 & 1.39 & 0.56 & 1.36 \\
\hline & RC30-DD-0.840-S & 161.6 & 117.4 & 267.5 & 176.0 & 1.38 & 0.60 & 0.92 \\
\hline & RC36-DS-0.24O-S & 99.1 & 86.1 & 130.6 & 92.3 & 1.15 & 0.76 & 1.07 \\
\hline & RC60-DS-0.24O-S & 107.1 & 100.2 & 143.2 & 107.4 & 1.07 & 0.75 & 1.00 \\
\hline & RC60-DS- $0.480-S$ & 143.7 & 113.4 & \begin{tabular}{|l|}
199.9 \\
\end{tabular} & 128.3 & 1.27 & 0.72 & 1.12 \\
\hline & RC21-RS-0.240-S & 68.6 & 36.9 & 46.3 & 46.3 & 1.86 & 1.48 & 1.48 \\
\hline \multicolumn{9}{|c|}{$\begin{array}{l}{ }_{\mathrm{b}} \mathrm{Q}_{\mathrm{su}}: \text { 大野·荒川min式による終局せん断耐力式(式(1)) } \\
\mathrm{V}_{\mathrm{u}}: \mathrm{A} \text { 法式によるせん断強度式(式(2)) }\end{array}$} \\
\hline
\end{tabular}
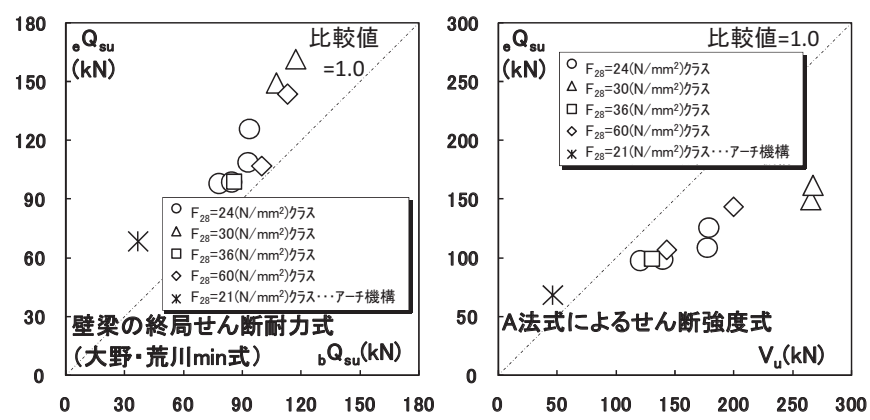

図5 最大耐力実験值 $\left({ }_{\mathrm{e}} \mathrm{Q}_{\mathrm{su}}\right)$ とせん断終局強度式による計算値との比較

試験体は，他の試験体に比べて耐力が最も低く，68.6(kN)であった。

表5に計算結果一覧を, 図5に最大耐力実験值 $\left(\mathrm{eQ}_{\mathrm{su}}\right)$ とせん断終 局強度式による計算值との比較を示す。せん断終局強度式は, 壁式 構造関係設計規準集・同解説（壁式鉄筋コンクリート造編）による 壁梁の終局せん断耐力（式(1)）（以下，大野・荒川 min 式）1)およ び鉄筋コンクリート造建物の終局強度型耐震設計指針・同解説によ るせん断強度式 A 法（式(2)）（以下，A 法式）5により検討を行う。 計算にあたり補強筋の降伏点は表2中の值を, コンクリート圧縮強 度は表3中の值を代入して計算を行った。また，アーチ機構のせん 断終局耐力を確認する No.10 試験体は式(1), 式(2)のトラス機構の 部分（式(1)では第 2 項, 式(2)では第 1 項）を無視して計算を行っ た。なお， $\mathrm{A}$ 法式の主筋中心間距離（ $\mathrm{j}_{\mathrm{t}}$ ) は, 最外縁主筋間距離を 採用して計算を行った。

\section{ロ大野·荒川 min 式による終局せん断耐力式口}

$$
{ }_{\mathrm{b}} \mathrm{Q}_{\mathrm{su}}=\left\{\frac{0.053 \mathrm{p}_{\mathrm{te}}{ }^{0.23}(\mathrm{Fc}+18)}{\mathrm{M} /(\mathrm{Q} \cdot \mathrm{d})+0.12}+0.85 \sqrt{\mathrm{p}_{\mathrm{we}}{ }_{\mathrm{s}} \sigma_{\mathrm{wy}}}\right\} \cdot \mathrm{b}_{\mathrm{e}} \cdot \mathrm{j}
$$

記号の意味は，文献 1)を参照のこと。

\section{口A 法式によるせん断強度式口}

$\mathrm{V}_{\mathrm{u}}=\mathrm{b} \cdot \mathrm{j}_{\mathrm{t}} \cdot \mathrm{p}_{\mathrm{w}} \cdot \sigma_{\mathrm{wy}} \cdot \cot \phi+\tan \theta \quad(1-\beta) \mathrm{b} \cdot \mathrm{D} \cdot v \cdot \sigma_{\mathrm{B}} / 2$

記号の意味は，文献 5)を参照のこと。

大野・荒川 min 式との比較では, 比較值 (=実験值/計算值) は 1.07 １.86の範囲となりすべて安全側の評価となった。比較值の平均值は 1.31 であった。また，せん断補強筋比の増加とともに比較值は大きく なり，安全率が高まる傾向が見られた。一方，A 法式との比較では， No.10 試験体の比較值は 1.48 となり安全側の評価となるものの，それ 
以外の試験体の比較值は $0.56 \sim 0.81$ となり危険側に評価された。せん 断補強筋比の増加とともに比較值は小さくなり, 危険側にプロットされ る傾向が認められた。以上のことから既往の計算式では, 補強筋のせん 断補強効果およびせん断終局耐力実験值を精度良く評価できていると は言い難い。

\section{4 せん断補強筋のひずみ度分布}

図6に要因ごとで比較した最大耐力時の補強筋のひずみ度と補強 筋の位置との関係を示す。コンクリート圧縮強度 $\sigma \mathrm{B}_{\mathrm{B}}=31.6 \sim 33.1$

$\left(\mathrm{N} / \mathrm{mm}^{2}\right)$ の範囲におけるせん断補強筋比 $\mathrm{p}_{\mathrm{w}}$ の影響では, 最大ひずみ 度の值は 1480～1810 $(\mu)$ 程度であり， $\mathrm{p}_{\mathrm{w}}$ の違いによる大きな差異 は認められない。同様に，コンクリート圧縮強度 $\sigma \mathrm{B}_{\mathrm{B}}=55.4\left(\mathrm{~N} / \mathrm{mm}^{2}\right)$ と共通にした場合の最大ひずみ度の值は 1850～2280( $\mu$ )であり, $\mathrm{p}_{\mathrm{w}}$ の違いによる傾向がみられない。とくに， $\sigma \mathrm{B}_{\mathrm{B}}=31.6 \sim 33.1\left(\mathrm{~N} / \mathrm{mm}^{2}\right)$ における試験体の補強筋のひずみ度は, 降伏ひずみ度に達する前に 最大耐力を迎える傾向が認められ，補強筋のせん断補強効果を十分 に発揮できていない。これは, 破壊性状において補強筋端部のフッ クが曲げ戻されていることから, 補強筋端部の定着能力が十分でな いために降伏ひずみ度に達しないと推察される。

次に，コンクリート圧縮強度 $\sigma \mathrm{B}$ 㞑響では，コンクリート強度 の上昇とともに，最大耐力時のひずみ度は大きくなり，せん断補強 筋が全体的に効果を発揮する傾向が認められる。これは, コンクリ 一ト圧縮強度が上昇したことにより, せん断補強筋端部の定着耐力 が向上したためと考えられる。そのために最大耐力時のひずみ度が 上昇し, 応力の再配分が可能になったと推察される。

せん断補強筋の形状による影響では, せん断補強量を共通にして閉 鎖型補強筋の試験体と非閉鎖型補強筋の試験体で比較した場合, 非 閉鎖型補強筋の場合は局部的に補強筋が効果を発揮しており，応力 が再配分できずに破壊が集中する傾向が認められる。一方，閉鎖型 補強筋の場合は全体的に補強筋が効果を発揮しており, 応力が再配 分できている傾向が認められる。

主筋の配筋による影響では, 破壊モードは異なるため参考程度となる が，最大ひずみ度は両者ともに $1500(\mu)$ 程度であり，単配筋と複配 筋による影響は認められない。

\section{4. せん断終局耐力の評価}

\section{1 最大耐力時のせん断補強筋の補強効果}

図7に最大耐力を決定づけたせん断ひび割れを横切る補強筋の採用 位置の一例, 図8に実応力度比 $\left(\sigma_{\mathrm{wm}} / \sigma_{\mathrm{wy}}\right)$ と補強筋の鉄筋係数 $\left(\mathrm{p}_{\mathrm{w}} \cdot \sigma_{\mathrm{wy}} / \sqrt{\sigma_{\mathrm{B}}}\right)$ 関係を示寸。ここに, 実応力度 $\sigma_{\mathrm{wm}}$ は図7に示寸よ うに最大耐力を決定づけたせん断ひび割れを横切る各せん断補強筋 の最大耐力時の応力度を相加平均したものであり,下式(3)により算出 したものである。

$$
\sigma_{\mathrm{wm}}=\frac{\sum_{\mathrm{i}=1}^{\mathrm{n}}\left(\mathrm{E}_{\mathrm{s}} \cdot \varepsilon_{\mathrm{wmi}}\right)}{\mathrm{n}}
$$

ただし， $\mathrm{E}_{\mathrm{s}} \cdot \varepsilon_{\mathrm{wmi}}>\sigma_{\mathrm{wy}}$ の場合は, $\mathrm{E}_{\mathrm{s}} \cdot \varepsilon_{\mathrm{wmi}}=\sigma_{\mathrm{wy}}$ とする。

ここに， $\mathrm{E}_{\mathrm{s}}$ : せん断補強筋のヤング係数（表2参照）

$\varepsilon_{\mathrm{wmi}}$ : 最大耐力を決定づけたせん断ひび割れを横切る

各せん断補強筋の最大耐力時のひずみ度（図7参照）

$\mathrm{n}$ : 最大耐力を決定づけたせん断ひび割れを横切る

せん断補強筋の本数（図7参照）
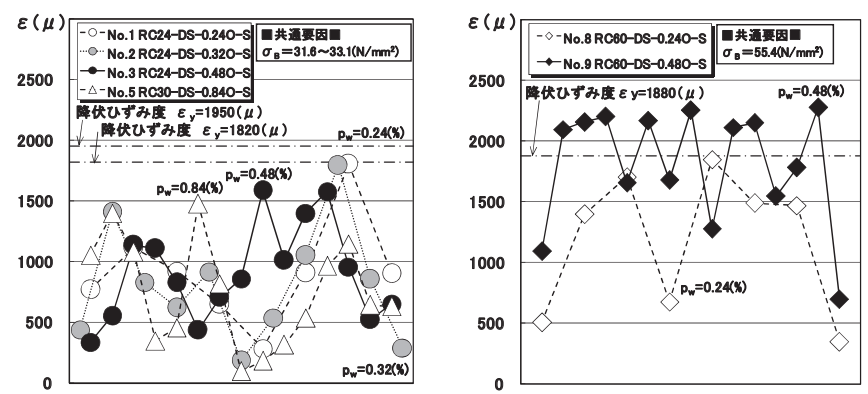

(せん断補強筋比 $\mathrm{p}_{\mathrm{w}}$ による影響)
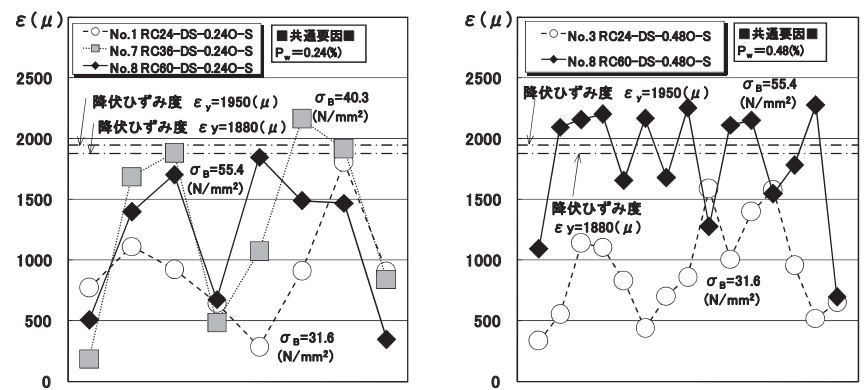

(コンクリート圧縮強度 $\sigma_{\mathrm{B}}$ による影響)

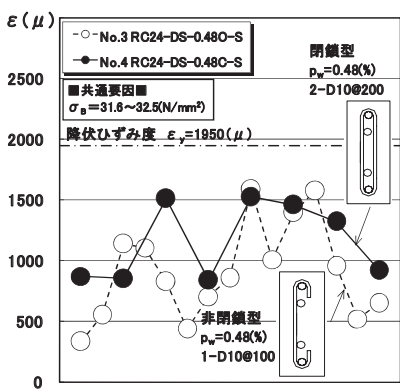

(せん断補強筋の形状による影響)

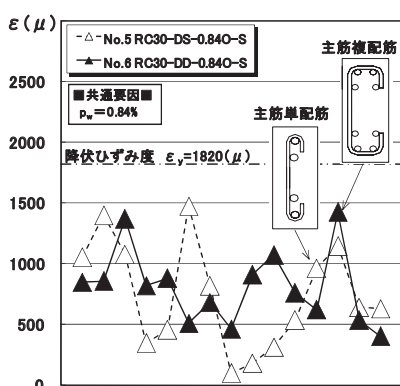

（主筋の配筋による影響）
図6 最大耐力時の補強筋のひず夕度と補強筋の位置との関係

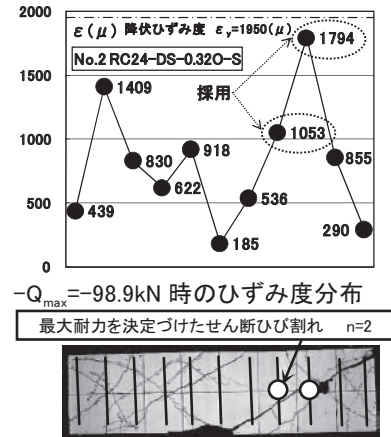

図7 せん断補強筋の 採用位置の一例

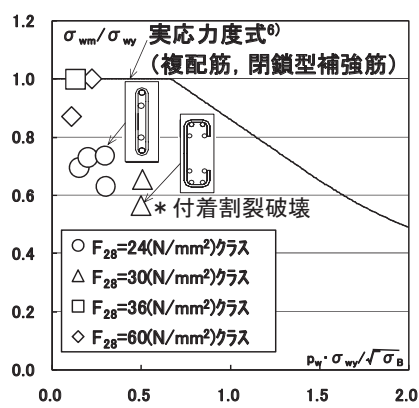

図8 実応力度比と 補強筋の鉄筋係数関係 $\sigma_{\mathrm{wy}}$ : せん断補強筋の降伏点（表2参照）

また, 比較のため同図中に磯, 松崎により提案された主筋が複配筋, 補強筋が閉鎖型補強筋の梁のせん断実験により得られた実応力度比 と補強筋の鉄筋係数との関係式 ${ }^{6}$ を実線で示しておく。実応力度比の 実験值は，鉄筋係数の増加とともに小さくなる傾向を示している。実 線で示した主筋が複配筋，せん断補強筋が閉鎖型とした試験体から得 られた関係式も同様な傾向を示している。しかし，主筋が単配筋，補 強筋が非閉鎖型のせん断補強効果（図8中のプロットした点）は，主 筋が複配筋，補強筋が閉鎖型のせん断補強効果（図8中の実線）に比 べて小さい傾向を示している。これは，破壊性状でも説明したが，主 筋が単配筋される場合の破壊の特徵として, 梁の上・下面に主筋に沿 
う割裂ひび割れが生じる。それにより補強筋端部の定着部も同時に損 傷することとなり, そのためにせん断補強筋の補強効果が十分に発揮 されないと考えられる。また, 実験終了後の観察で補強筋端部のフッ クが曲げ戻されていることからも，おおむねそのような要因によるも のと推察される。

\section{2 せん断補強筋定着部 ( $180^{\circ}$ フック部分) の抵抗機構モデル}

亀田, 小倉 ${ }^{7)}$ は, せん断補強筋末端部を対象としたフックの定着性 能試験から，135フックおよび $90^{\circ}$ フックの定着部がすべり破壊する 場合の定着強度推定式を提案している。その提案式は, フック定着筋 の塑性曲げ戻し抵抗力, フック湾曲部の付着力, 余長部の付着力を累 加した式となっている。

塑性曲げ戻し抵抗力 $\sigma \mathrm{H} 1$ は式(4)により評価している。 $\sigma \mathrm{H} 1=(0.38-0.024 \mathrm{R}) \sigma_{\mathrm{wy}}$

ここに, $\sigma_{\mathrm{wy}}$ : せん断補強筋の降伏点 $\left(\mathrm{N} / \mathrm{mm}^{2}\right)$

$\mathrm{R}$ : 補強筋フックの折曲げ内法直径を補強筋径で除した值 フック湾曲部の付着力 $\sigma$ H 2 および余長部の付着力 $\sigma$ H3 平均付着応力度をそれぞれ $\tau_{\mathrm{b} 1}=0.4 \mathrm{~F}_{\mathrm{c}}, \tau_{\mathrm{b} 2}=0.35 \mathrm{~F}_{\mathrm{c}}$ と仮定して, 当該 部分の補強筋の表面積を乗じて, 断面積で除して算出している。なお, 上記で示した $\tau_{\mathrm{b} 1}, \tau_{\mathrm{b} 2}$ は補強筋端部が $135^{\circ}$ フックとしたものに対し て提案されたものであるが, $180^{\circ}$ フックにも適用できるものとすると, $\sigma$ H2 は式(5) となる。

$$
\begin{aligned}
\sigma \mathrm{H}_{2}=0.4 \mathrm{~F}_{\mathrm{c}}\left\{\left(\pi\left(\mathrm{D}+\mathrm{d}_{\mathrm{b}}\right) / 2\right\} \cdot \pi \cdot \mathrm{d}_{\mathrm{b}} /\left(\pi \cdot \mathrm{d}_{\mathrm{b}} 2 / 4\right)\right. \\
=0.8 \mathrm{~F}_{\mathrm{c}} \cdot \pi\left(\mathrm{D}+\mathrm{d}_{\mathrm{b}}\right) / \mathrm{d}_{\mathrm{b}}=0.8 \mathrm{~F}_{\mathrm{c}} \cdot \pi(\mathrm{R}+1) \\
\text { ここに, } \mathrm{F}_{\mathrm{c}}: \text { コンクリート圧縮強度 }\left(\mathrm{N} / \mathrm{mm}^{2}\right) \\
\mathrm{D}: \text { 補強筋フックの折曲げ内法直径 }(\mathrm{mm}) \\
\mathrm{d}_{\mathrm{b}}: \text { 補強筋径 }(\mathrm{mm}) \\
\text { その他の記号は, 式(4)を参照。 }
\end{aligned}
$$

また， $\sigma$ н3 は式(6) となる。

$\sigma_{\mathrm{H}_{3}}=0.35 \mathrm{~F}_{\mathrm{c}} \cdot 1 \cdot \pi \cdot \mathrm{d}_{\mathrm{b}} /\left(\pi \cdot \mathrm{d}_{\mathrm{b}}{ }^{2} / 4\right)=1.4 \mathrm{~F}_{\mathrm{c}} \cdot 1 / \mathrm{d}_{\mathrm{b}}$

ここに, $1:$ 補強筋フックの余長 $(\mathrm{mm})$

その他の記号は，式(5)を参照。

以上, 式(4), 式(5), 式(6)を累加すると, $180^{\circ}$ フックを想定した 定着強度推定式 (式(7)) を得る。

$\sigma_{\mathrm{Hb}}=(0.38-0.024 \mathrm{R})_{\sigma_{\mathrm{wy}}}+0.8 \mathrm{~F}_{\mathrm{c}} \cdot \pi(\mathrm{R}+1)+1.4 \mathrm{~F}_{\mathrm{c}} \cdot \mathrm{l} / \mathrm{d}_{\mathrm{b}}$

記号の意味は，式(4)，式(5)，式(6)を参照。

図9に4.1節で算出した補強筋の実応力度 $(\sigma \mathrm{wm})$ と式(7)による定 着強度 $(\sigma \mathrm{Hb})$ との比較を示す。なお, 実験值は閉鎖型補強筋の No.4 試験体, 付着破壊した No.6 試験体, アーチ機構の耐力を確認する No.10 試験体は除いている。実応力度は, 式(7)による定着強度よりも 小さな值となっており, 部材においては, その定着能力を十分に発揮 できていない。その要因とし て部材実験では, 補強筋のフ ック定着部にせん断ひび割れ や上面・下面に割裂ひび割れ が生じるなど, 定着部のコン クリートに損傷が生じる。そ のため, 十分な定着が確保で きていない可能性がある。式 （7）は，無損傷のコンクリート に埋め込まれ補強筋フック部

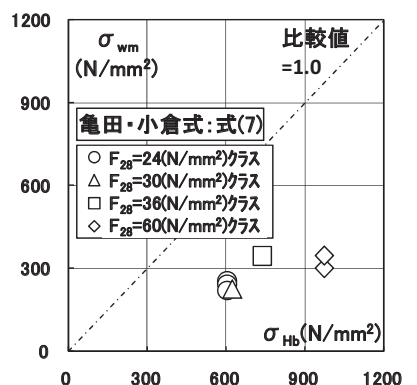

図9 補強筋の実応力度 $(\sigma$,$) と$ 式 $(7)$ による定着強度 $\left(\sigma_{\mathrm{Hb}}\right)$ との比較

を直接引き抜く試験方法により得られた結果から導出され式であり, 部材における定着の状態とはやや異なることが懸念される。

本試験体の破壊性状と補強筋のひずみ度の性状から補強筋の定着 部は最大耐力時において滑り出している状態にあると判断し, 亀田, 小倉の提案を参考にして，図10に示す $180^{\circ}$ フック定着部の抵抗モ デルを考える。図10(a)は，フック部の曲げ戻し抵抗力をモデル化し たものである。フック起点の $\mathrm{A}$ 点部分を固定端とし, フックと主筋の 接点を $\mathrm{B}$ 点とおく。主筋には，トラス機構の圧縮束応力により突き上 げ力が生じる。そのため主筋を介して B 点には, フックを持ち上げる 方向に集中荷重 $\mathrm{T}_{\mathrm{r}}$ が生じると仮定すると, $\mathrm{A}$ 点には, その反力とし て張力 $\mathrm{T}_{\mathrm{r}}$ とモーメント $\mathrm{M}_{\mathrm{r}}\left(=\mathrm{T}_{\mathrm{r}} \cdot\left(\mathrm{D}+\mathrm{d}_{\mathrm{b}}\right) / 2\right)$ が生じる。ここで， $\mathrm{A}$ 点 の鉄筋断面に生じる引張側縁応力度が降伏点 $\sigma \mathrm{wy}$ に達した状態を終 局状態と仮定すると, フック部の曲げ戻しによる抵抗力 $\mathrm{T}_{\mathrm{r}}$ は式(8) と なる。

$$
\begin{aligned}
& \mathrm{T}_{\mathrm{r}}=\frac{\sigma_{\mathrm{wy}} \cdot \mathrm{A}_{\mathrm{s}} \cdot \pi \cdot \mathrm{d}_{\mathrm{b}}{ }^{3}}{\pi \cdot \mathrm{d}_{\mathrm{b}}{ }^{3}+16 \mathrm{~A}_{\mathrm{s}}\left(\mathrm{D}+\mathrm{d}_{\mathrm{b}}\right)} \\
& \text { ここに, } \mathrm{A}_{\mathrm{s}}: \text { せん断補強筋の断面積 }\left(\mathrm{mm}^{2}\right) \\
& \text { その他の記号は, 式(4), 式(5)を参照。 }
\end{aligned}
$$

図10(b)は，フック湾曲部分および余長部分の付着力による抵抗力 をモデル化したものである。フック湾曲部分および余長部分に生じる 平均付着応力度を $\tau$ bu と仮定し, 定着長さをフック湾曲部分と余長部 分の和と考えると，付着力による抵抗力 $\mathrm{T}_{\mathrm{b}}$ は式(9) となる。

$\mathrm{T}_{\mathrm{b}}=\tau_{\mathrm{bu}} \cdot\left\{\left(\pi\left(\mathrm{D}+\mathrm{d}_{\mathrm{b}}\right) / 2+1\right\} \cdot \pi \cdot \mathrm{d}_{\mathrm{b}}\right.$

記号の意味は，式(5)，式(6)を参照。

ここで，せん断補強筋の定着部を $180^{\circ}$ フックにした場合の定着耐 力 $\mathrm{T}_{\mathrm{a}}$ は, 式(8), 式(9)の累加と考えると式(10)となる。

$\mathrm{T}_{\mathrm{a}}=\mathrm{T}_{\mathrm{r}}+\mathrm{T}_{\mathrm{b}}$

よって, 補強筋の定着強度推定式は, 式(10)を補強筋の断面積 $\mathrm{A}_{s}$ で除して式(11)となる。

$\sigma_{\mathrm{wa}}=\mathrm{T}_{\mathrm{a}} / \mathrm{A}_{\mathrm{s}}$

ここで, 式(9)中の付着強度 $\tau$ buは，森田・藤井式 8)を採用して検討 を行う。ただし，補強筋の項は無視した式(12)により行い，式中の割 裂線長さ比 $b_{i}$ は図11に示すサイドスプリット型の破壊モードを仮定 して算定する。

$$
\tau_{\text {bu }}=\left(0.307 b_{i}+0.427\right) \sqrt{F_{c}}
$$

ここに, $\mathrm{F}_{\mathrm{c}}$ : コンクリート圧縮強度 $\left(\mathrm{kgf} / \mathrm{cm}^{2}\right)$
$b_{i}$ は，割裂線長さ比で次式による。
$b_{\mathrm{i}}=\mathrm{b} /\left(\mathrm{N} \cdot \mathrm{d}_{\mathrm{b}}\right)-1$
$\mathrm{b}$ : 部材の幅 $\mathrm{N}$ : 割裂部分の補強筋の本数
$\mathrm{d}_{\mathrm{b}}$ : 補強筋径

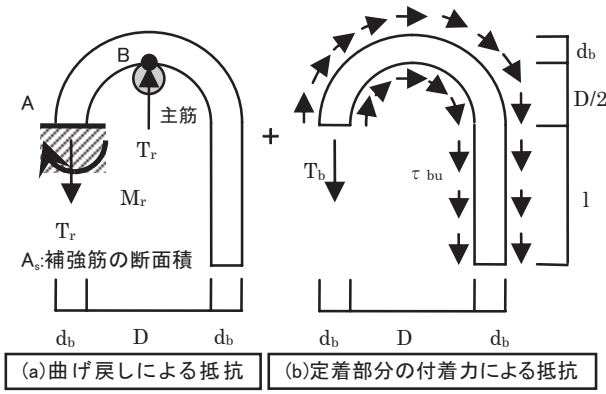

図10 $180^{\circ}$ フック定着部の抵抗モデル

図

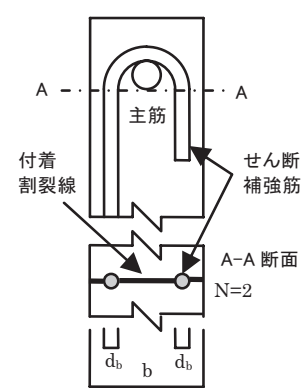

11 付着割裂モード の仮定 
図12に補強筋の実応力度（ $\sigma$ wm） と $\tau$ bu に森田・藤井式を採用 した場合の式(11)による補強筋の 定着強度（ $\sigma$ wa $)$ との比較を示す。 なお，図9と同様に No.4，No.6， No.10 試験体のデータは除いてい る。実応力度は式(11)による定着強 度に比べて, やや高く安全側の評 価となっている。しかし, 図9に比 べて, 実験值は比較值（=実験值／ 計算值） 1.0 付近に近付いており， 推定精度は式(7)に比較して良い。比較值は $1.03 \sim 1.44$, 比較值の平 均は 1.21 であった。

\section{3 主筋が単配筋された RC 薄肉断面梁部材のせん断終局強度}

本項では, 主筋が単配筋された RC 薄肉断面梁部材のせん断抵抗モ デルを提案し, せん断終局強度式を提案する。前述より $\mathrm{A}$ 法式によ るせん断終局強度との比較では, 実験值は危険側に評価された。そ の理由として 2 点挙げられる。1 点目は, カバーコンクリートの損 傷に比べてコアコンクリートの損傷がひどく, 応力がコア部に集中 していること。2 点目は, 補強筋の定着部が損傷するために十分な 補強効果を発揮できないことが考えられる。

以上の点を勘案して, A 法式を修正することを試みる。1 点目は, コア部に応力が集中することから，トラス機構の作用幅を全梁幅で はなく作用有効幅が存在することとする。つまり, 作用有効幅内に 応力を集中させるモデルとする。2 点目は, 補強筋のせん断補強効 果は, フック部の定着耐力により決定されるため, A 法式のトラス 機構における $\sigma \mathrm{wy}$ を, 式(11)の $\sigma \mathrm{wa}$ に変更する。以上をもとに修正 した A 法式を式(13)に，そのせん断抵抗モデルを図 13 に示す。

${ }_{\text {MA }} \mathrm{V}_{\mathrm{u}}=\mathrm{b}_{\mathrm{e}} \cdot \mathrm{j}_{\mathrm{t}} \cdot \mathrm{p}_{\mathrm{we}} \cdot \sigma_{\mathrm{wa}} \cdot \cot \phi+\tan \theta(1-\beta) \mathrm{b} \cdot \mathrm{D} \cdot v \cdot \sigma_{\mathrm{B}} / 2$

ただし, $\mathrm{p}_{\mathrm{we}} \cdot \sigma_{\mathrm{wa}}>v \cdot \sigma_{\mathrm{B}} / 2$ の時, $\mathrm{p}_{\mathrm{we}} \cdot \sigma_{\mathrm{wa}}=v \cdot \sigma_{\mathrm{B}} / 2$ とする。

ここに, $b_{\mathrm{e}}$ : トラス機構の作用有効幅 $(=2 \times$ 主筋の最外径 $)$ $\mathrm{j}_{\mathrm{t}}$ : 主筋中心間距離 (ここでは, 最外縁主筋間距離を採用) $\mathrm{p}_{\mathrm{we}}$ : 有効横補強筋比 $\left(=\mathrm{a}_{\mathrm{w}} /\left(\mathrm{b}_{\mathrm{e}} \cdot \mathrm{s}\right)\right)$

$\mathrm{a}_{\mathrm{w}}$ : 横補強筋の断面積 $\mathrm{s}$ : 横補強筋の間隔

$\sigma_{\mathrm{wa}}$ : 補強筋の定着強度 (式(11))

ただし， $\sigma_{\mathrm{wa}}>\sigma_{\mathrm{wy}}$ の場合は, $\sigma_{\mathrm{wa}}=\sigma_{\mathrm{wy}}$ とする。

$\tan \theta=\sqrt{\left[(\mathrm{L} / \mathrm{D})^{2}+1\right]}-\mathrm{L} / \mathrm{D}$

$\beta=\left\{\left(1+\cot ^{2} \phi\right) \mathrm{p}_{\mathrm{we}} \cdot \sigma_{\mathrm{wa}}\right\} /\left(v \cdot \sigma_{\mathrm{B}}\right)$

$\nu=0.7-\sigma_{\mathrm{B}} / 200$

$\cot \phi$ の值は下式による值のうち最小のものとする。

$\cot \phi=\min \left(2.0, \mathrm{j}_{\mathrm{t}} /(\mathrm{D} \cdot \tan \theta), \quad \sqrt{v \sigma_{\mathrm{B}} /\left(\mathrm{p}_{\mathrm{we}} \cdot \sigma_{\mathrm{wa}}\right)-1.0}\right)$

その他の記号は，文献 5)参照

\section{口適用範囲}

断面 : $\mathrm{b} \times \mathrm{D}=150(\mathrm{~mm}) \times 400(\mathrm{~mm})$

せん断スパン比 : $a / D=2.0$

せん断補強筋比 : $\mathrm{p}_{\mathrm{w}}=0.24 \sim 0.84(\%)$

コンクリート強度 : $\sigma_{\mathrm{B}}=21.1 \sim 55.4\left(\mathrm{~N} / \mathrm{mm}^{2}\right)$

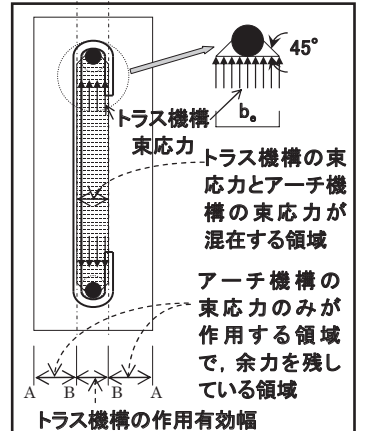

図13 せん断抵抗モデル

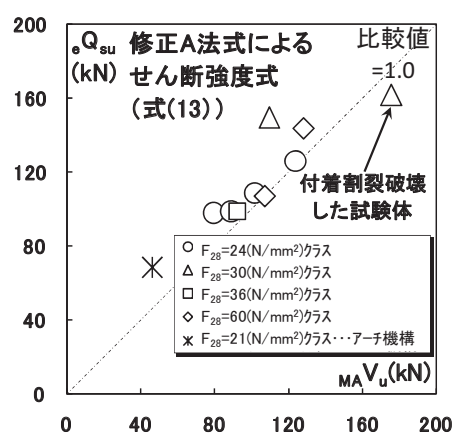

図14 最大耐力実験值 $\left(\mathrm{e}_{\mathrm{su}}\right)$ と 式(13)の提案式による計算值との比較 なお，本式中の主筋中心間距離（jt）は，最外縁の主筋間距離を 採用している。トラス機構は, 主筋の付着力, せん断補強筋の張力, コンクリートの圧縮束応力の釣り合いで構成される機構であること から，その 3 力が交わる位置は最外縁の主筋位置であることから， それを採用したものである。また, 本モデルはトラス機構の作用有 効幅を主筋の最外径の 2 倍（B-B 区間）と仮定している。理由であ るが，本モデルでは，トラス機構の圧縮束応力を主筋を突き上げる 力としてとらえており，せん断補強筋はその突き上げ力を抑え込ん でいる役割をしていると考えている。しかし，その考え方からすれ ば，圧縮束応力の作用幅は，主筋の最外径とするのが適切である。 しかし, 主筋に付着しているコンクリート部分（ここでは，主筋の 直径から 45 度方向に出したラインと主筋断面下端の平行ラインと が交わる範囲（図13の $b_{\mathrm{e}}$ 部分））も圧縮束応力を抑え込むことが 可能な領域と考えたためである。また，有効幅を設けた理由は，卜 ラス機構の作用有効幅を設定することによりトラス機構とアーチ機 構によるコンクリート圧縮束応力が混在する領域となる。つまり， コアコンクリート部に応力が集中する現象をモデル化させたもので ある。ただし，両束応力の加算は，コンクリート有効圧縮強度（v・ $\sigma$ B）以下とする。

また, 図13のトラス機構作用有効幅以外の部分（A-B 区間）は, トラス機構による束応力は作用せず，アーチ機構による束応力のみ が作用する領域となる。つまり，余力を残した状態で終局耐力にな る領域を意味する。破壞性状においても，断面中心部分の B-B 区間 に破壊が集中しており, A-B 区間に相当する部分のコンクリートは, ひび割れが若干入るものの, 健全な部分が比較的多く存在する。以 上のことから，本モデルはおおむ称実現象に近い状態を再現してい るものと考えられる。図 14 亿最大耐力実験值 $\left({ }_{\mathrm{e}} \mathrm{Q}_{\mathrm{su}}\right)$ と式(13)の提 案式による計算值との比較を, 表 5 に計算結果一覧を示す。なお, 計 算にあたり閉鎖型補強筋の No.4 試験体は， $\sigma$ wa に降伏点強度を代入 して計算している。また, No.6 試験体の $\sigma$ wa の計算にあたり, 式(8) の曲げ戻しによる抵抗力 $\mathrm{T}_{\mathrm{r}}$ は, 並列した 1 段筋の主筋 2 本から集中 荷重を受けて曲げ戻されていると仮定して計算している。一方, 式(9) の付着力による抵抗力 $\mathrm{T}_{\mathrm{b}}$ は, 主筋間の補強筋の直線部分 $50 \mathrm{~mm}$ も付 着長さに加えて計算している。No.10 試験体はアーチ機構の耐力のみ と考えて式(13)の第一項を無視して計算している。

同図より，付着破壊した No.6 試験体を除いた他の試験体はすべて 安全側に評価できている。また，付着破壊した No.6 試験体，アーチ 機構の耐力を調查する No.10 試験体を除いた比較值（=実験值／計算 值）は $1.00 \sim 1.36$ の範囲にあり，比較值の平均値は 1.12 であること 
から，おおむね良い精度で評価できている。No.10 試験体の安全率が 1.48 と高いが, これは最終破壊状況においてひび割れはほとんど入っ ていなことから, ひび割れによる圧縮強度低減係数 $v$ の值は, 計算さ れる值よりも高くなっているためと推察される。

次に, 図 15 に最大耐力の実験值 $\left(\mathrm{e}_{\mathrm{su}}\right)$ と有効せん断補強量 $\left(\mathrm{p}_{\mathrm{we}}\right.$ ・ $\left.\sigma_{\mathrm{wa}}\right)$ との関係を示す。比較のため同図中に式(13)による值を実線で, 松崎・武藤らによる上面割裂による付着割裂強度提案式 ${ }^{9)}$ の值も同図 中に示しておく。本提案式は, 単配筋された $\mathrm{RC}$ 梁のせん断終局耐力 実験值と有効せん断補強との関係をおおむね評価できている。ただし， No.5 試験体の実験值は, 式(13)のせん断終局強度式と付着割裂強度式 のラインよりも安全側の評価となっている。この要因の一つは, 式 (13)中の補強筋の定着強度 $\sigma$ wa $の$ 評価が, 実験值に対して大きく安全 側に評価されているためであり, 今後, 補強筋の定着強度の推定精度 を高める必要があると考えられる。No.6 試験体の実験における破壊 モードは二段筋の付着割裂破壊に対して, 計算上ではせん断破壊の判 定となり破壊モードが異なる。しかし, 実験值はおおむね付着割裂破 壊のラインに近接しており, おおむ㸚実験值の傾向をとらえている。

\section{5. まとめ}

・主筋を単配筋，せん断補強筋を非閉鎖型とした薄肉断面 $\mathrm{RC}$ 梁部 材の破壊性状は，梁の上・下面に割裂ひび割れをともないせん断 破壊する脆性的な性状を示した。また，カバーコンクリートの損 傷に比較してコアコンクリート部分に損傷が集中する傾向が認 められた。

・主筋を単配筋，せん断補強筋を非閉鎖型とした試験体のせん断終 局耐力は，せん断補強筋比，コンクリート強度の上昇とともに高 くなる傾向が認められた。また，そのせん断終局耐力は，主筋を 複配筋とした試験体，せん断補強筋を閉鎖型とした試験体に比較 して，やや低下する傾向を示した。

・主筋を単配筋，せん断補強筋を非閉鎖型とした試験体は，補強筋 端部の定着部の損傷により，十分な補強効果を発揮せずに破壊に いたる傾向が認められた。

・180゚フックで定着されたせん断補強筋の補強効果評価式を提案 した。また，その効果を考慮に入れて主筋が単配筋された薄肉断 面 $\mathrm{RC}$ 梁部材のせん断終局強度式を提案し, 本提案式によりおお むね実験值を推定できることを示した。

\section{謝辞}

本試験体製作に当たっては，東京鉄鋼株式会社に鉄筋を提供頂き ました。ここに記して深甚の謝意を表します。

\section{参考文献}

1) 日本建築学会 : 壁式構造関係設計規準集・同解説（壁式鉄筋コンクリート造 編), 2003. 9

2）米澤良弘，石橋一彦，橋爪顕一，園部泰寿：薄肉部材のせん断補強に関 寸る実験的研究, 日本建築学会大会学術講演梗概集, pp. 1789 1799, 1983.9

3）古里健司，永坂具也：シングル配筋されたあばら筋を有する RC 梁，日本 建築学会大会学術講演梗概集，C-2，pp. 645 646, 2000.9

4）金子順一, 中野克彦, 松崎育弘, 太田勤, 田嶋光春, 園部泰寿 : 組立鉄筋 ユニットを用いた $\mathrm{RC}$ 造基礎梁の構造性能に関する実験的研究 (その 2 . せん 断実験), 日本建築学会学術講演梗概集, C-2, pp. 283 284, 2001.9

5）日本建築学会 : 鉄筋コンクリート造建物の終局強度型而震設計指針・同解説, 1990. 11
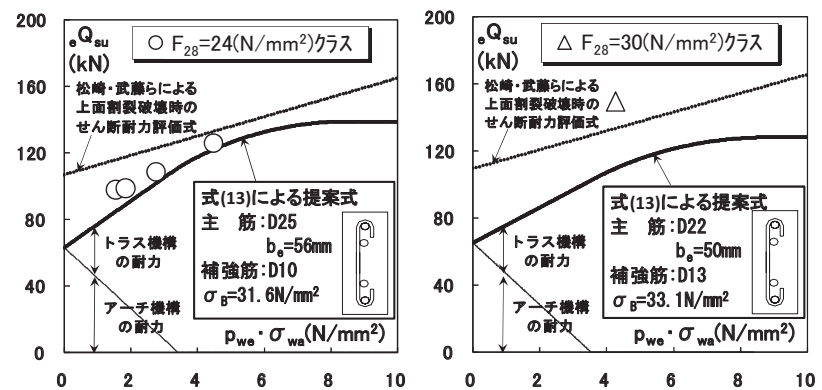
No.1,2,3,4 試験体
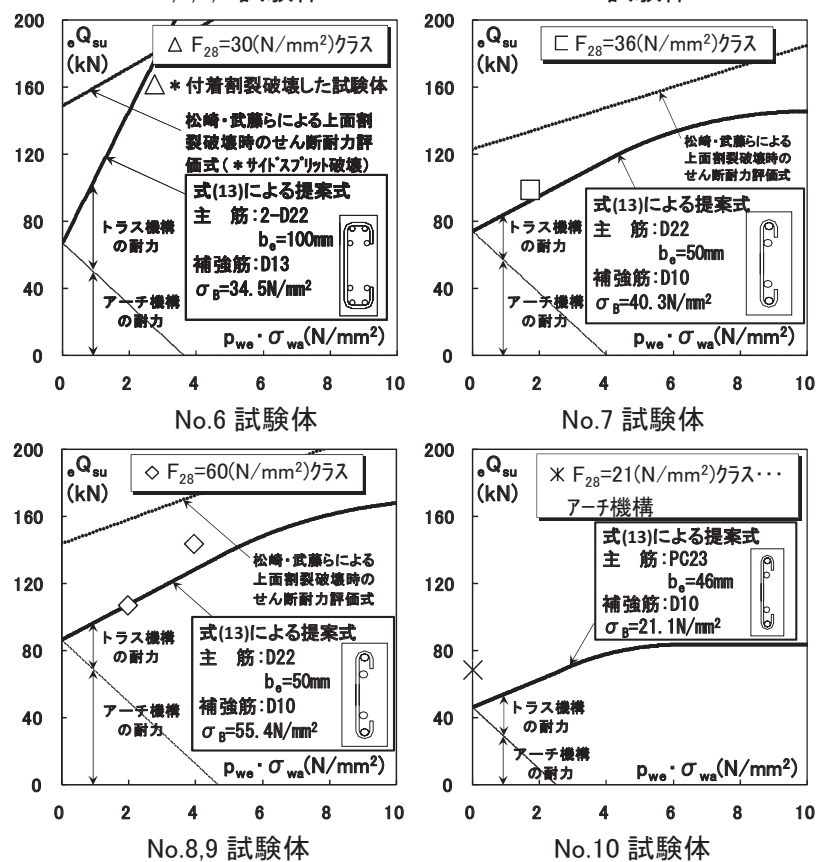

図 15 最大耐力実験值 $\left(\mathrm{Q}_{\mathrm{Su}}\right)$ と

有効せん断補強量 $\left(\mathrm{p}_{\mathrm{we}} \cdot \sigma_{\mathrm{wa}}\right)$ との関係

6）渡辺英義，松崎育弘，磯雅人：鉄筋コンクリート梁部材におけるせん断補 強筋の補強効果に関する実験研究 (その $1 \sim 2$ ), 日本建築学会学術講演梗概 集, pp. 275〜278，1991.9

7）亀田登与三郎，小倉弘一郎：せん断補強筋末端部を対象とするフック定着 性能，日本建築学会学術講演梗概集，C，pp. 673〜 674，1994.9

8）藤井栄，森田司郎：異形鉄筋の付着割裂強度に関寸る研究 一第 1 報 付 着割裂破壊を支配する要因についての実験結果一, 日本建築学会論文報告集, 第 319 号, pp. 47〜 55，1982.9

9）武藤剛，松崎育弘，杉山智昭，金木美奈子：主筋がシングルに配筋された $\mathrm{RC}$ 梁部材の構造性能に関する実験的研究，コンクリート工学年次論文集， Vol. 28-2, pp. 271 275, 2006. 7

(2008年 5 月 27 日原稿受理，2008年 9 月 5 日採用決定） 